Article

\title{
The Usability of Pumice Powder as a Binding Additive in the Aspect of Selected Mechanical Parameters for Concrete Road Pavement
}

\author{
Abdulrezzak Bakis \\ Department of Civil Engineering, Bitlis Eren University, Bitlis 13100, Turkey; arezzakbakis@gmail.com
}

Received: 14 July 2019; Accepted: 23 August 2019; Published: 27 August 2019

\begin{abstract}
In this study, the usability of pumice powder and lime in concrete production as a binding additive for rigid superstructure concrete road pavement was investigated. Following the determination of the optimum binder ratio, these new binder ratios were used in crushed limestone concrete production. The concrete thus formed was named concrete containing cement, pumice powder and lime (PPCC). The normally produced concrete, without pumice powder and lime binder was selected as reference concrete (RC). Regarding the total binder amount of the most appropriate binder ratio $50 \%$ was found to be cement, $30 \%$ pumice powder and $20 \%$ lime in the result of the study. In consequence of the study, the $20 \pm 2{ }^{\circ} \mathrm{C}$ and 7-28 days compressive strengths of the reference concrete were found to be $33.8 \mathrm{MPa}$ and $38.2 \mathrm{MPa}$ and its bending strengths were 4.2 MPa and 4.7 MPa. The $20 \pm 2{ }^{\circ} \mathrm{C}$ and 7-28 days compressive strengths of PPCC were found to be $25.1 \mathrm{MPa}$ and $28.3 \mathrm{MPa}$ and its bending strengths were 3.2 MPa and 3.5 MPa. The results of the study showed the usability of PPCC in concrete pavement.
\end{abstract}

Keywords: pumice; lime; concrete road pavement; compressive strength; bending strength

\section{Introduction}

The term "pumice" is called "ponce" in French, whereas the stones with medium particle size are called "pumice" in English [1]. Pumice stone formations, which are formed because of volcanic events and have a cavernous, spongy structure, are found in many regions of the world where volcanic activities take place [2]. Pumice contains numerous pores ranging from macro scale to micro scale due to the sudden release and sudden cooling of the gases it embodies during its formation. Since there are disconnected caverns between the pores, its permeability is low and heat and sound insulation is quite high [3]. Today, the use of pumice is developing day by day when compared with the past, and it is being used in various fields. Its usage in other sectors is newly becoming widespread [4]. Pumice sources identified around the world are approximately 18 billion $\mathrm{m}^{3}$ [5]. Especially regarding pumice beds, Bitlis province has significant potential due to both volcanic area and geological structure. The beds in question are located in the Tatvan district of Bitlis province and 81,500,000 $\mathrm{m}^{3}$ pumice beds of good quality are available [6,7]. As the pumice grain grows, the grain specific gravity decreases. Pore percentage increases as grain sizes increase. Pumice is a very light, pyroclastic magmatic rock type shaped during the volcanic eruption. The lava is shaped in liquid form, including gas bubbles, throughout the period in which it spurts out into the air as gas froth [8]. Pumice is especially used in the production of trass cement. When pumice stones are ground with cement fineness and then mixed with cement or lime, they acquire a binding property. These types of volcanic rocks are called pozzolana [9]. Small crystals of various minerals are found in pumices, which have an amorphous structure. The most common crystals are feldspar, augite, hornblende and zircon. Pumice is much 
lighter than sand and gravel [10]. Pumice sand is one of the solid wastes polluting the environment and causing the formation of dumpsites.

When processing pumice extracted from quarries, a significant amount of pumice sand is produced. Waste materials should be evaluated for their possible uses. Pumice is a pyroclastic rock type [11]. Pumice contains several independent pores, each separated from the other by a glassy membrane [12]. The construction of rigid pavements has been rapidly becoming widespread in airports, in structures like runways, in terminals, loading, unloading and parking areas and partially in places like urban roads, etc.

Considering the increasing number of commercial vehicles in the world with each passing day, the use of concrete pavements as road superstructures is expected to become widespread in the future [13]. Overall, it is almost imperative that roads, bearing $8.2 \mathrm{t}$ of standard axle load number of which are more than $60-75 \times 10^{6}$ within a 20-year period and airports with more than 5000 departures of large passenger airplanes yearly, are constructed as rigid pavements. In the specifications for the proportioning of concrete pavement, a few of the criteria considered are maximum $\mathrm{w} / \mathrm{c}$ ratio being $0.40-0.45$, minimum compressive strength being $280 \mathrm{~kg} / \mathrm{cm}^{2}$ and minimum amount of cement being $270-335 \mathrm{~kg} / \mathrm{m}^{3}$ [14]. In buildings and similar structures, water/cement ratio is expected not to exceed $55 \%$ [15]. Materials that are initially thin, which turn into dough when water is added, and that do not dissolve in water by hardening over time are called binding materials.

The use of these materials dates back to ancient times. The most commonly used binders are oily lime, cement and gypsum. Before cement was found in the 19th century, soil and limestone mixtures, different limes and gypsums, baked clay and other binders (volcanic tuffs, trass, zeolite, diatomite and natural soils) were used as binding materials [16]. The materials that can harden under water are called hydraulic binders. The use of these binders coincides with the Hellenistic period of 2300 years ago. In the town of Pozzuoli, near Naples, it was discovered by the Romans that this soil, made up of ashes emanating from the Vesuvius volcano, was superior to plain lime mortar when mixed with lime [17]. Natural or artificial additives such as pozzolanic substance, which do not exhibit binding properties on their own but acquire binding property in aqueous media when mixed with lime in a very finely ground state are called pozzolanic additives.

Since the compressive strength of pumice, which has a significant amount of pores in macro and micro dimensions is very low, its areas of usage in the construction sector have remained limited and it has mainly been used in wall and plaster construction aimed at insulation, in filter material production in water treatment units, in grinding and polishing jobs in the textile industry, in torching material production in match factories and in similar sectors. Pumice aggregate is finitely used for insulation purposes in concrete production sector, but it cannot be used as building concrete in the carrier parts of the structure since the compressive strength of the aggregate is very low. This study was prepared with the aim of providing the widespread use of concrete elements that will be formed with pumice powder in the construction sector. It is possible to use other materials with a binding property such as pozzolanic rock powders in certain ratios together with cement in order to reduce the cost in concrete production [13]. In their study, Hattatoglu and Bakis (2017) used ignimbrite powder as a binding additive and thus obtained high-strength concrete [18].

In this study, pumice powder and lime were found to have a significant binding effect on concrete when mixed with cement. In this study, a new type of concrete production was developed by using pumice powder (PP) and lime (L) together with cement. The compressive and bending strengths of the concrete samples produced in this way were found to be high and the concrete production cost was reduced by reducing the amount of cement per $\mathrm{m}^{3}$ in production. In this study, cement, crushed stone (gravel-sand) and water containing normal concrete production, which are generally used in construction sector, were prepared for the purpose of comparison and the samples to be formed were selected as reference concrete.

In this study, the usability of pumice powder and lime in concrete production as a binding additive for concrete road pavement was investigated. Pumice powder with dimensions of $0-0.04 \mathrm{~mm}$ was 
used in the study. Seventy-two types of concrete samples were formed in different mixing ratios, with pumice powder. The optimum ratios of pumice powder and lime as the binding additive were determined in consequence of all the experiments. Following the determination of the optimum binder ratio, these new binder ratios were used in crushed limestone concrete production. Compressive and bending strength tests of the new concrete produced were performed. The concrete thus formed was named concrete containing cement, pumice powder and lime (PPCC). The concrete produced without pumice powder and lime binder, only with cement binder was selected as reference concrete (RC). RC and PPCC concrete were cured with standard water curing of 7 and 28 days. Following water curing, compressive and bending strength tests were performed on all concrete samples. The results of the study showed the usability of PPCC in concrete pavement.

\section{Materials and Methods}

\subsection{Materials}

CEM I 42.5 R type cement, which complies with TS EN 197-1 (EN 197-1:2011) (2012) standard, was used in all experiments [19]. Chemical properties of CEM I $42.5 \mathrm{R}$ cement are given in Table 1 [20].

Table 1. CEM I 42.5 R cement chemical properties.

\begin{tabular}{cc}
\hline \multicolumn{2}{c}{ Chemical Properties \% } \\
\hline $\mathrm{SiO}_{2}$ & 18.90 \\
$\mathrm{Al}_{2} \mathrm{O}_{3}$ & 5.15 \\
$\mathrm{Fe}_{2} \mathrm{O}_{3}$ & 3.36 \\
$\mathrm{CaO}$ & 63.59 \\
$\mathrm{MgO}$ & 1.57 \\
$\mathrm{SO}_{3}$ & 2.65 \\
Loss of Ignition & 3.59 \\
$\mathrm{~K}_{2} \mathrm{O}$ & 0.77 \\
$\mathrm{Na}_{2} \mathrm{O}$ & 0.40 \\
$\mathrm{Cl}$ & 0.02 \\
\hline
\end{tabular}

The cement appearance is given in Figure 1.

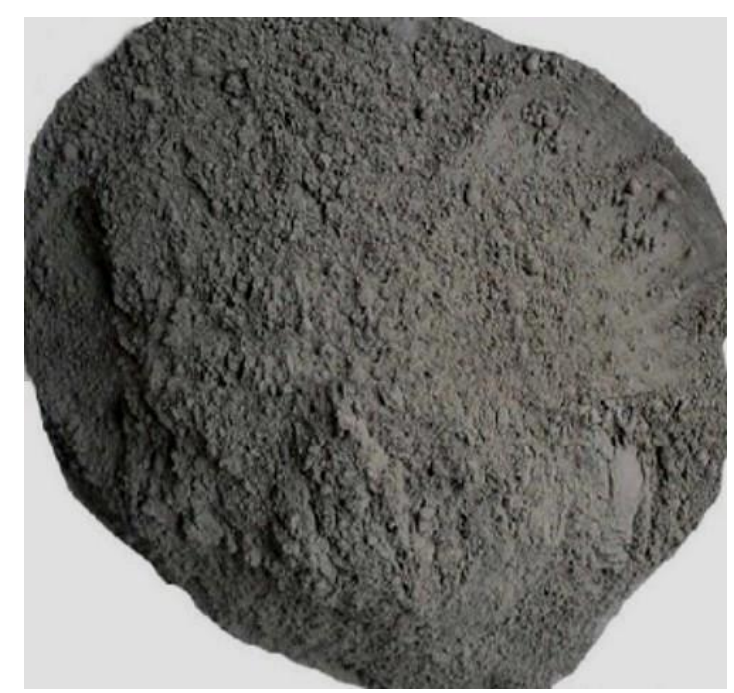

Figure 1. CEM I $42.5 \mathrm{R}$ cement appearance.

Potable Bitlis city water was used in the experiments. Pumice powder is shown in Figure 2. 


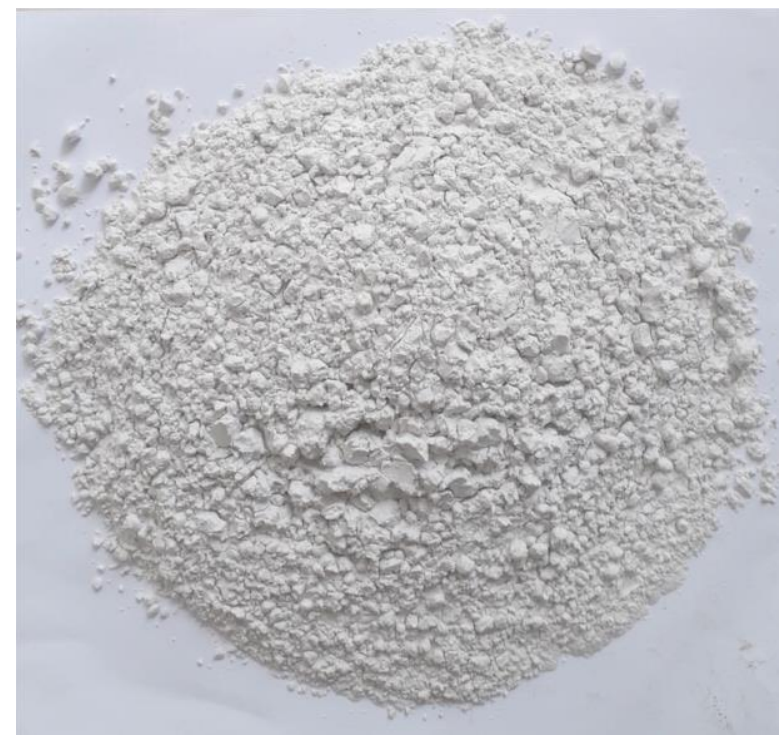

Figure 2. Pumice powder.

Pumice powder grain diameter was between $0-0.04 \mathrm{~mm}$. Specific gravity of slacked lime was $2.2 \mathrm{~g} / \mathrm{cm}^{3}$ (Miner Mining Transportation Trade Limited Company) [21] and complied with the TS EN 459-1 (2017) (EN 459-1:2015) standard [22]. The lime view is shown in Figure 3.

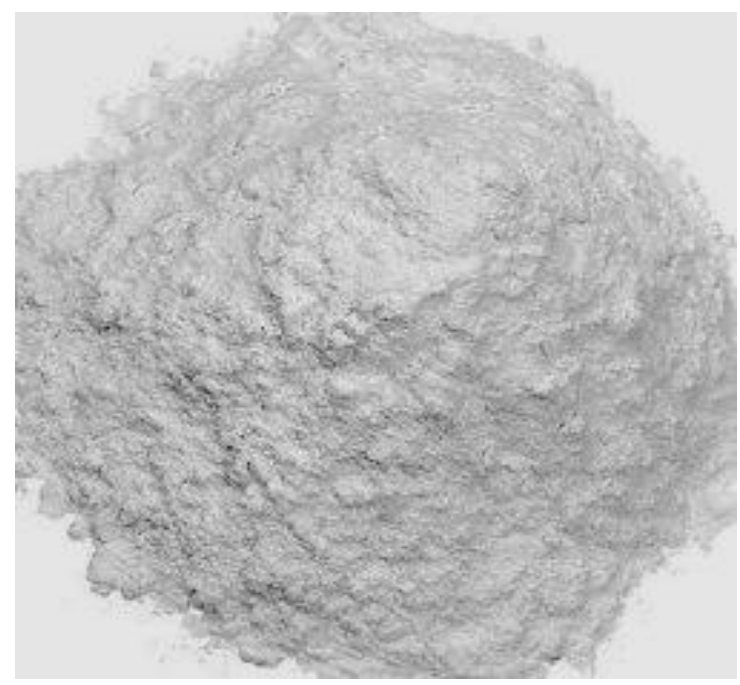

Figure 3. Lime.

The chemical properties of pumice and lime are shown in Table $2[23,24]$.

Table 2. Chemical properties of pumice and lime.

\begin{tabular}{|c|c|c|c|c|c|c|c|c|}
\hline Sample & Loss of Ignition (\%) & $\mathrm{MgO}(\%)$ & $\mathrm{Al}_{2} \mathrm{O}_{3}(\%)$ & $\mathrm{SiO}_{2}(\%)$ & $\mathrm{Na}_{2} \mathrm{O}+\mathrm{K}_{2} \mathrm{O}(\%)$ & $\mathrm{CaO}(\%)$ & $\mathrm{Fe}_{2} \mathrm{O}_{3}(\%)$ & $\mathrm{Ca}(\mathrm{OH})_{2}(\%)$ \\
\hline Pumice & 3 & 0.6 & 14 & 70 & 9 & 0.9 & 2.5 & - \\
\hline Lime & 7 & 3 & - & - & - & 85 & - & 80 \\
\hline
\end{tabular}

The pumice powder used as cement additive must comply with TS 25 (TS 25/T1) (2008) Trass Standard. It was indicated in the TS 25 (TS 25/T1) (2008) Trass Standard prepared by TSE (Turkish Standardization Institute) that the $\mathrm{SiO}_{2}+\mathrm{Al}_{2} \mathrm{O}_{3}+\mathrm{Fe}_{2} \mathrm{O}_{3}$ total should at least have the ratio of $70 \%$ [25]. As shown in Table 2, the pumice powder $\mathrm{SiO}_{2}+\mathrm{Al}_{2} \mathrm{O}_{3}+\mathrm{Fe}_{2} \mathrm{O}_{3}$ was $86.5 \%$ in total. This ratio indicates that pumice powder can be used as binder. For comparison purposes, physical and mechanical properties of pumice, cement, and lime are shown in Table $3[26,27]$. 
Table 3. Physical and mechanical properties of pumice, cement, and lime.

\begin{tabular}{cccc}
\hline Property & Pumice & Cement & Lime \\
\hline Specific gravity $\left(\mathrm{g} / \mathrm{cm}^{3}\right)$ & 2.415 & 3.130 & 1.800 \\
\hline Water absorption by weight $(\%)$ & 22.59 & - & - \\
\hline Los Angeles abrasion $(\%)$ & 73 & - & - \\
\hline
\end{tabular}

One of the highest cost items in concrete production is the amount of cement used in production. In this study, the compressive strengths of samples formed by using pumice powder (PP) and lime (L) together with cement $(C)$ were calculated in order to reduce the amount of cement. Seventy-two different mixture types were formed for the determination of the optimum binder ratio. With all the mixtures formed to determine the appropriate binder ratio, the water/binder ratio was considered as 0.60 . Consistency and workability were not influenced by the substitution. Three samples from each type of mixture were taken, and the average of these three values was calculated. The prepared mixtures are shown in Figure 4.

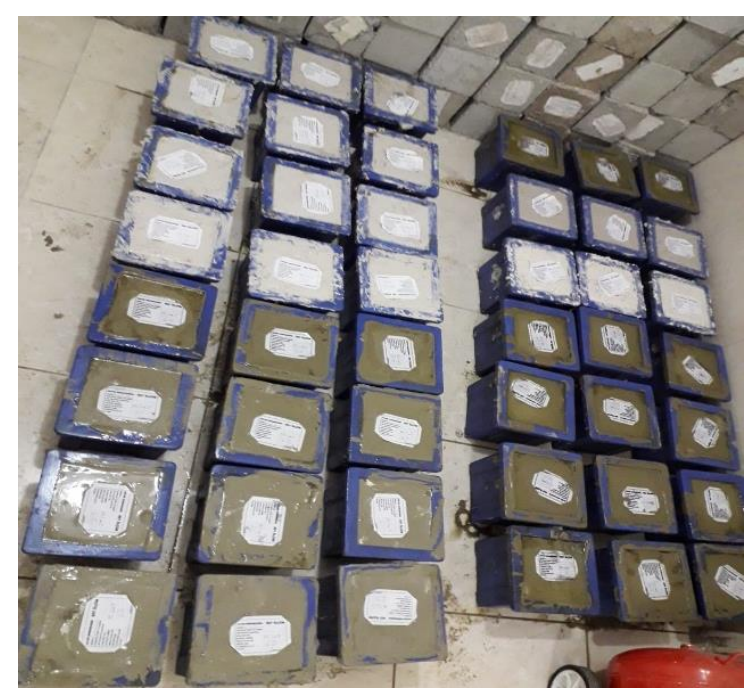

Figure 4. Mixtures prepared for optimum binding.

\subsection{Methods}

\subsubsection{Binder Mixing Ratios}

\section{Type-1 Mixing Ratios}

Type-1 mixing ratios are shown in Table 4. The mixture contained cement, pumice powder and water. There was no lime in the mixture.

Six different types of mixture were formed by taking $0 \%, 20 \%, 40 \%, 60 \%, 80 \%$ and $100 \%$ of the cement amount.

Table 4. Type-1 Mixing Ratios.

\begin{tabular}{cccc}
\hline Mixture Type & Cement (C) (\%) & Pumice Powder (\%) & Lime (\%) \\
\hline $1-1$ & 100 & 0 & 0 \\
$1-2$ & 80 & 20 & 0 \\
$1-3$ & 60 & 40 & 0 \\
$1-4$ & 40 & 60 & 0 \\
$1-5$ & 20 & 80 & 0 \\
$1-6$ & 0 & 100 & 0 \\
\hline
\end{tabular}


As shown in Table 4 and Figure 5, the 1-1 mixture was the binder's reference mortar for optimal binder fixation. Only cement was used as binder in the reference mortar.

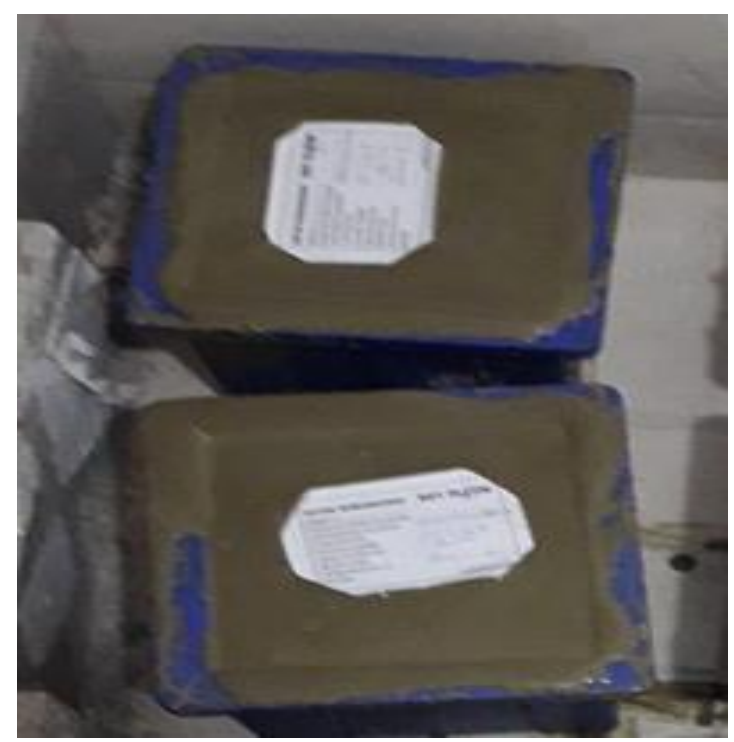

Figure 5. Binder reference mortar for optimum binder fixation.

As shown in Table 4 and Figure 6, only pumice powder was used as the binder in the mixture mortar 1-6.

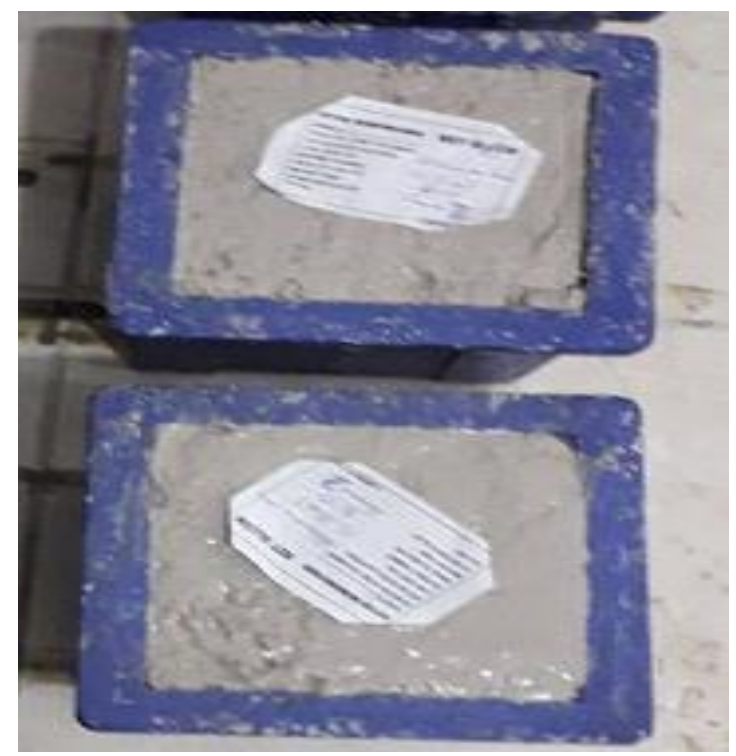

Figure 6. Pumice binder mortar for optimum binder fixation.

\section{Type-2 Mixing Ratios}

Type- 2 mixing ratios are shown in Table 5 . The mixture contained pumice powder, lime and water. There was no cement in the mixture. 
Table 5. Type-2 mixing ratios.

\begin{tabular}{cccc}
\hline Mixture Type & Cement (C) (\%) & Pumice Powder (\%) & Lime (\%) \\
\hline $2-1$ & 0 & 100 & 0 \\
$2-2$ & 0 & 80 & 20 \\
$2-3$ & 0 & 60 & 40 \\
$2-4$ & 0 & 40 & 60 \\
$2-5$ & 0 & 20 & 80 \\
$2-6$ & 0 & 0 & 100 \\
\hline
\end{tabular}

Six different types of mixture were formed by taking $0 \%, 20 \%, 40 \%, 60 \%, 80 \%$ and $100 \%$ of the pumice powder amount as lime amount.

As shown in Table 5 and Figure 7, only lime was used as binder in the mixture mortar 2-6.

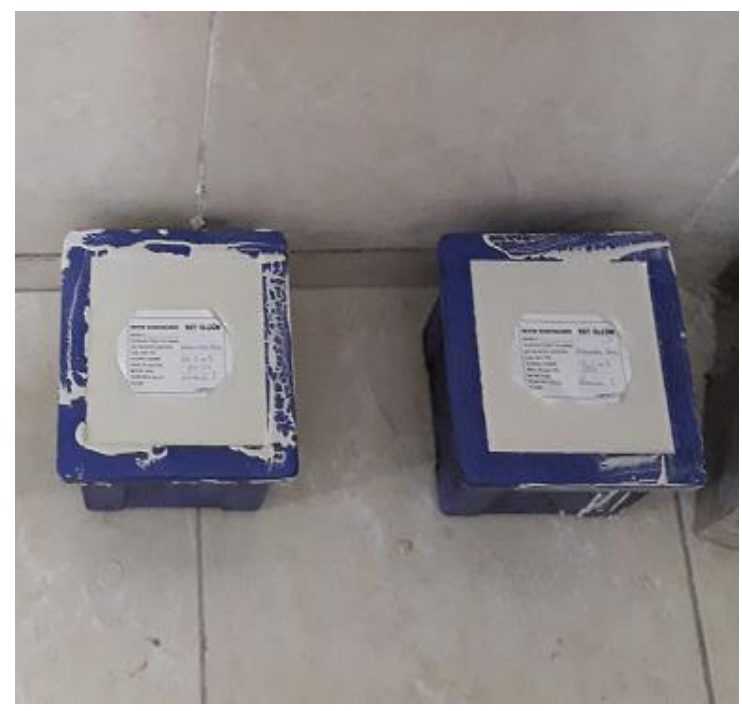

Figure 7. Lime binder mortar for optimum binder fixation.

Type-3 Mixing Ratios

Type-3 mixing ratios are shown in Table 6. The mixture contained cement, lime and water. There was no pumice powder in the mixture.

Table 6. Type-3 mixing ratios.

\begin{tabular}{cccc}
\hline Mixture Type & Cement (C) (\%) & Pumice Powder (\%) & Lime (\%) \\
\hline $3-1$ & 100 & 0 & 0 \\
$3-2$ & 80 & 0 & 20 \\
$3-3$ & 60 & 0 & 40 \\
$3-4$ & 40 & 0 & 60 \\
$3-5$ & 20 & 0 & 80 \\
$3-6$ & 0 & 0 & 100 \\
\hline
\end{tabular}

Six different types of mixture were formed by taking $0 \%, 20 \%, 40 \%, 60 \%, 80 \%$ and $100 \%$ of the cement amount as lime amount.

\section{Type-4 Mixing Ratios}

Type-4 mixtures included cement, pumice powder, lime and water. The mixing ratio of each type was different. Nine different types of mixtures were produced from Type- 4 mixtures. 


\section{Type-4-1 Mixing Ratios}

Type 4-1 mixing ratios are shown in Table 7 . In this section, the mixing ratio with the highest compressive strength was considered.

Table 7. Type-4-1 mixing ratios.

\begin{tabular}{cccc}
\hline Mixture Type & Cement (C) $\mathbf{( \% )}$ & Pumice Powder (\%) & Lime (\%) \\
\hline $4-1-1$ & 80 & 20 & 0 \\
$4-1-2$ & 64 & 20 & 16 \\
$4-1-3$ & 48 & 20 & 32 \\
$4-1-4$ & 32 & 20 & 48 \\
$4-1-5$ & 16 & 20 & 64 \\
$4-1-6$ & 0 & 20 & 80 \\
\hline
\end{tabular}

In the mixture ratio with the highest compressive strength, six different types of mixture were formed by considering the amount of lime as $0 \%, 20 \%, 40 \%, 60 \%, 80 \%$ and $100 \%$ of the cement amount.

Type-4-2 Mixing Ratios

Type-4-2 mixing ratios are shown in Table 8. In this section, the mixing ratio with the highest compressive strength in the second type mixture was considered.

Table 8. Type-4-2 mixing ratios.

\begin{tabular}{cccc}
\hline Mixture Type & Cement (C) (\%) & Pumice Powder (\%) & Lime (\%) \\
\hline $4-2-1$ & 80 & 20 & 0 \\
$4-2-2$ & 80 & 16 & 4 \\
$4-2-3$ & 80 & 12 & 8 \\
$4-2-4$ & 80 & 8 & 12 \\
$4-2-5$ & 80 & 4 & 16 \\
$4-2-6$ & 80 & 0 & 20 \\
\hline
\end{tabular}

In the mixture ratio with the highest compressive strength, six different types of mixture were formed by considering the amount of lime as $0 \%, 20 \%, 40 \%, 60 \%, 80 \%$ and $100 \%$ of the pumice powder amount.

\section{Type-4-3 Mixing Ratios}

Type-4-3 mixing ratios are shown in Table 9. In this section, the mixing ratio with the highest compressive strength in the first type mixture was considered.

Table 9. Type 4-3 mixing ratios.

\begin{tabular}{cccc}
\hline Mixture Type & Cement (C) (\%) & Pumice Powder (\%) & Lime (\%) \\
\hline $4-3-1$ & 80 & 20 & 0 \\
$4-3-2$ & 66.6 & 16.7 & 16.7 \\
$4-3-3$ & 57.1 & 14.3 & 28.6 \\
$4-3-4$ & 50.0 & 12.5 & 37.5 \\
$4-3-5$ & 44.4 & 11.2 & 44.4 \\
$4-3-6$ & 40.0 & 10.0 & 50 \\
\hline
\end{tabular}

In the mixture ratio with the highest compressive strength, six different types of mixture were formed by considering the amount of lime as $0 \%, 20 \%, 40 \%, 60 \%, 80 \%$ and $100 \%$ of the (cement + pumice powder) amount. 
Type-4-4 Mixing Ratios

Type-4-4 mixing ratios are shown in Table 10. In this section, the mixing ratio with the highest compressive strength in the second type mixture was considered.

Table 10. Type 4-4 mixing ratios.

\begin{tabular}{cccc}
\hline Mixture Type & Cement (C) (\%) & Pumice Powder (\%) & Lime (\%) \\
\hline $4-4-1$ & 0 & 60 & 40 \\
$4-4-2$ & 10 & 50 & 40 \\
$4-4-3$ & 17 & 43 & 40 \\
$4-4-4$ & 22.5 & 37.5 & 40 \\
$4-4-5$ & 26.7 & 33.3 & 40 \\
$4-4-6$ & 30 & 30 & 40 \\
\hline
\end{tabular}

In the mixture ratio with the highest compressive strength, six different types of mixture were formed by considering the amount of cement as $0 \%, 20 \%, 40 \%, 60 \%, 80 \%$ and $100 \%$ of the pumice powder amount.

\section{Type-4 Mixing Ratios}

Type-4-5 mixing ratios are given in Table 11. In this section, the mixing ratio with the highest compressive strength in the second type mixture was considered.

Table 11. Type 4-5 Mixing Ratios.

\begin{tabular}{cccc}
\hline Mixture Type & Cement (C) (\%) & Pumice Powder (\%) & Lime (\%) \\
\hline $4-5-1$ & 0 & 60 & 40 \\
$4-5-2$ & 6.7 & 60 & 33.3 \\
$4-5-3$ & 11.4 & 60 & 28.6 \\
$4-5-4$ & 15 & 60 & 25 \\
$4-5-5$ & 17.8 & 60 & 22.2 \\
$4-5-6$ & 20 & 60 & 20 \\
\hline
\end{tabular}

In the mixture ratio with the highest compressive strength, six different types of mixture were formed by considering the amount of cement as $0 \%, 20 \%, 40 \%, 60 \%, 80 \%$ and $100 \%$ of the lime amount. Type-4-6 Mixing Ratios

Type-4-6 mixing ratios are presented in Table 12. In this section, the mixing ratio with the highest compressive strength in the second type mixture was considered.

Table 12. Type 4-6 mixing ratios.

\begin{tabular}{cccc}
\hline Mixture Type & Cement (C) (\%) & Pumice Powder (\%) & Lime (\%) \\
\hline $4-6-1$ & 0 & 60 & 40 \\
$4-6-2$ & 16.7 & 50 & 33.3 \\
$4-6-3$ & 28.6 & 42.8 & 28.6 \\
$4-6-4$ & 37.5 & 37.5 & 25 \\
$4-6-5$ & 44.4 & 33.4 & 22.2 \\
$4-6-6$ & 50 & 30 & 20 \\
\hline
\end{tabular}

In the mixture ratio with the highest compressive strength, six different types of mixture were formed by considering the amount of cement as $0 \%, 20 \%, 40 \%, 60 \%, 80 \%$ and $100 \%$ of the (pumice powder + lime) amount. 
Type-4-7 Mixing Ratios

Type-4-7 mixing ratios are given in Table 13. In this section, the mixing ratio with the highest compressive strength in the third type mixture was considered.

Table 13. Type 4-7 mixing ratios.

\begin{tabular}{cccc}
\hline Mixture Type & Cement (C) $(\%)$ & Pumice Powder (\%) & Lime (\%) \\
\hline $4-7-1$ & 80 & 0 & 20 \\
$4-7-2$ & 64 & 16 & 20 \\
$4-7-3$ & 48 & 32 & 20 \\
$4-7-4$ & 32 & 48 & 20 \\
$4-7-5$ & 16 & 64 & 20 \\
$4-7-6$ & 0 & 80 & 20 \\
$4-8-1$ & 80 & 0 & 20 \\
\hline
\end{tabular}

In the mixture ratio with the highest compressive strength, six different types of mixture were formed by considering the amount of pumice powder as $0 \%, 20 \%, 40 \%, 60 \%, 80 \%$ and $100 \%$ of the cement amount.

Type-4-8 Mixing Ratios

Type-4-8 mixing ratios are shown in Table 14. In this section, the mixing ratio with the highest compressive strength in the third type mixture was considered.

Table 14. Type 4-8 mixing ratios.

\begin{tabular}{cccc}
\hline Mixture Type & Cement (C) (\%) & Pumice Powder (\%) & Lime (\%) \\
\hline $4-8-1$ & 80 & 0 & 20 \\
$4-8-2$ & 80 & 4 & 16 \\
$4-8-3$ & 80 & 8 & 12 \\
$4-8-4$ & 80 & 12 & 8 \\
$4-8-5$ & 80 & 16 & 4 \\
$4-8-6$ & 80 & 20 & 0 \\
\hline
\end{tabular}

In the mixture ratio with the highest compressive strength, six different types of mixture were formed by considering the amount of pumice powder as $0 \%, 20 \%, 40 \%, 60 \%, 80 \%$ and $100 \%$ of the lime amount.

\section{Type-4-9 Mixing Ratios}

Type-4-9 mixing ratios are shown in Table 15. In this section, the mixing ratio with the highest compressive strength in the third type mixture was considered.

Table 15. Type 4-9 mixing ratios.

\begin{tabular}{cccc}
\hline Mixture Type & Cement (C) (\%) & Pumice Powder (\%) & Lime (\%) \\
\hline $4-9-1$ & 80 & 0 & 20 \\
$4-9-2$ & 66.6 & 16.7 & 16.7 \\
$4-9-3$ & 57.1 & 28.6 & 14.3 \\
$4-9-4$ & 50.0 & 37.5 & 12.5 \\
$4-9-5$ & 44.4 & 44.4 & 11.2 \\
$4-9-6$ & 40.0 & 50.0 & 10.0 \\
\hline
\end{tabular}


In the mixture ratio with the highest compressive strength, six different types of mixture were formed by considering the amount of pumice powder as $0 \%, 20 \%, 40 \%, 60 \%, 80 \%$ and $100 \%$ of the (cement + lime) amount.

Samples prepared for optimum binder fixation were prepared for 7-day compressive strength determination and each mixture was prepared as three pieces in total, with dimensions of $150 \times 150 \times$ $150 \mathrm{~mm}$. Samples were cured for 7 days at $20 \pm 2{ }^{\circ} \mathrm{C}$ by standard water curing. Samples taken into the curing pool are shown in Figure 8.

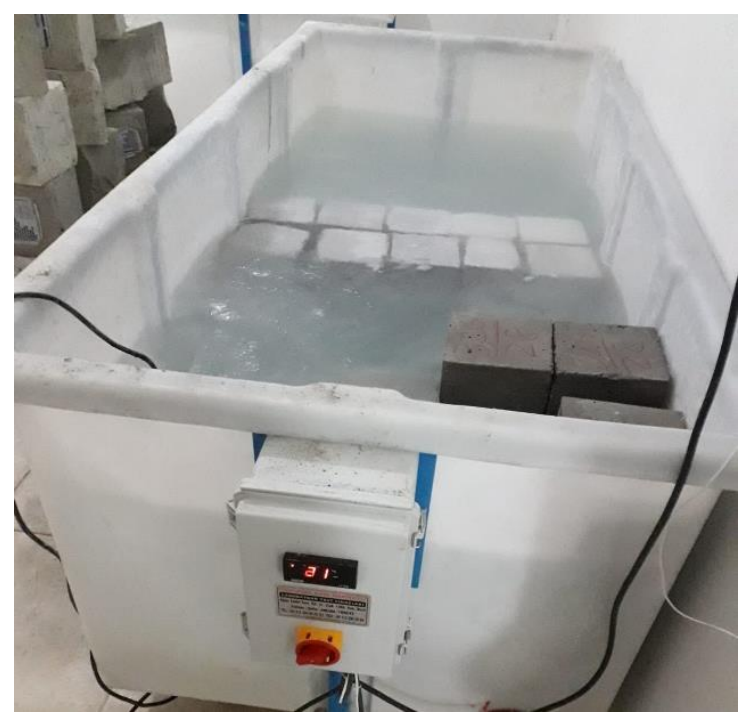

Figure 8. Curing pool.

\subsubsection{Reference Concrete Mixing Ratios}

In reference concrete production, CEM I 42.5 R type cement, which complied with TS EN 197-1 (EN 197-1:2011) standards, crushed limestone as aggregate and Bitlis city water qualifying as drinking water for concrete mixing water were used. Reference concrete class was taken as C30/37. In the study, reference concrete samples were prepared for 7 and 28 days of daily compressive strength determination, in dimensions of $150 \times 150 \times 150 \mathrm{~mm}$. being three each and six in total. Three samples were cured with a $20 \pm 2{ }^{\circ} \mathrm{C}$ standard water curing of 7 days, and the other three samples were cured with a $20 \pm 2{ }^{\circ} \mathrm{C}$ standard water curing of 28 days. The curing pool is shown in Figure 8 . The quantities of reference concrete materials are shown in Table 16.

Table 16. Reference concrete material quantities.

\begin{tabular}{cc}
\hline Materials & Quantity $\mathbf{( k g / \mathbf { m } ^ { 3 } )}$ \\
\hline Portland Cement & 450 \\
Crushed Stone $(0-4 \mathrm{~mm})$ & 792 \\
Crushed Stone $(4-8 \mathrm{~mm})$ & 388 \\
Crushed Stone $(8-16 \mathrm{~mm})$ & 581 \\
Water & 189 \\
\hline Total & 2400 \\
\hline
\end{tabular}

Six pieces of samples with dimensions of $100 \times 100 \times 400 \mathrm{~mm}$ were prepared for bending strength. three samples were treated with a $20 \pm 2{ }^{\circ} \mathrm{C}$ standard water curing of 7 days, and the other three samples were treated with a $20 \pm 2{ }^{\circ} \mathrm{C}$ standard water curing of 28 days. The curing pool is shown in Figure 8. Compressive and bending strength tests of samples after curing were performed. TS EN 12390-3 (2010) standard (EN 12390-3/2001) [28] was used in the compressive strength test, and the TS EN 12390-5 (2010) standard (EN 12390-5:2000) [29] was used in the bending strength test. 


\subsubsection{Mixing Ratios of Concrete with Optimum Binding Ratio (PPCC)}

In the production of PPCC, CEM I $42.5 \mathrm{R}$ type cement, $0-0.04 \mathrm{~mm}$ pumice powder and lime were used as binders in accordance with TS EN 197-1 standards (EN 197-1:2011). Potable Bitlis city water was used as aggregate for crushed limestone and concrete mixed water. C30/37 concrete class was considered in PPCC concrete production. Three samples from each type of mixture were taken, and the average of these three values was calculated. The material mixing ratios obtained at the optimum binder ratio are shown in Table 17.

Table 17. Amounts of concrete material at optimum binder ratio.

\begin{tabular}{cc}
\hline Materials & Quantity $\left.\mathbf{( k g} / \mathbf{m}^{\mathbf{3}}\right)$ \\
\hline Portland Cement & 225 \\
Pumice powder $(0-0.04 \mathrm{~mm})$ & 135 \\
Lime & 90 \\
Crushed Stone $(0-4 \mathrm{~mm})$ & 792 \\
Crushed Stone $(4-8 \mathrm{~mm})$ & 388 \\
Crushed Stone $(8-16 \mathrm{~mm})$ & 581 \\
Water & 189 \\
\hline Total & 2400 \\
\hline
\end{tabular}

The water/binder ratio of the concrete (PPCC) prepared in the ratio of reference concrete $(\mathrm{RC})$ and optimum binder were taken as 0.42 as shown in Tables 16 and 17 .

\subsubsection{Sieve Analysis Method}

The recommended slump value for pavement concrete is $3 \mathrm{~cm}$ according to Table 18 [14].

Table 18. Coating concrete slump values.

\begin{tabular}{ccc}
\hline \multirow{2}{*}{ Type of Concrete } & \multicolumn{2}{c}{ Slump, cm } \\
\cline { 2 - 3 } & Minimum & Maximum \\
\hline Coating, Precast, Roller Compacted Concrete & $1-2$ & $3-4$ \\
Mass Concrete & 2.5 & 5.0 \\
Reinforced Concrete (Very Equipped) & 2.5 & 10 \\
Reinforced Concrete (Less Equipped) & 2.5 & 7.5 \\
\hline
\end{tabular}

For $3 \mathrm{~cm}$ slump, the Water/Cement $(\mathrm{W} / \mathrm{C})$ value of which is 0.42 , the cement amount was considered as $450 \mathrm{~kg} / \mathrm{m}^{3}$ and the approximate water amount according to the $\mathrm{w} / \mathrm{c}$ ratio as $189 \mathrm{~kg} / \mathrm{m}^{3}$. The mix design target strength for $0.42 \mathrm{w} / \mathrm{c}$ ratio was found to be $380 \mathrm{~kg} / \mathrm{cm}^{2}$ (38 MPa) [14]. Table 19 shows the approximate $\mathrm{w} / \mathrm{c}$ ratios according to the concrete compressive strengths. Since the maximum $\mathrm{w} / \mathrm{c}$ ratio in the coating concrete is desired to be between $0.40-0.45$, for the non-air entrained concrete, the w/c ratio of which was 0.42 , an average target compressive strength was found, the 28 days compressive strength of which was $40 \mathrm{MPa}[16,30]$.

Table 19. Approximate water/cement ratios according to concrete compressive strengths.

\begin{tabular}{ccc}
\hline Compressive Strength (28 Days) & \multicolumn{2}{c}{ Water/Cement Ratio } \\
\cline { 2 - 3 } $\mathbf{1 5 0} \times \mathbf{3 0 0} \mathbf{~ m m}$ Cylinder (MPa) & Non-Air Entrained Concrete & Air Entrained Concrete \\
\hline 15 & 0.79 & 0.70 \\
20 & 0.69 & 0.60 \\
25 & 0.61 & 0.52 \\
30 & 0.54 & 0.45 \\
35 & 0.47 & 0.39 \\
40 & 0.42 & 0.33 \\
45 & 0.37 & 0.29 \\
50 & 0.33 & 0.25 \\
\hline
\end{tabular}


In accordance with Table 19, reference concrete (RC) and optimum binder concrete (PPCC) class were established as $\mathrm{C} 30 / 37$, considering the mean target compressive strength. C30/37 concrete properties can be seen in Table $20[16,30]$.

Table 20. Average compressive strengths according to concrete classes.

\begin{tabular}{ccccc}
\hline Concrete Category & \multicolumn{2}{c}{ Characteristic Compressive Strength (MPa) } & \multicolumn{2}{c}{ Target Compressive Strength (MPa) } \\
\cline { 2 - 5 } & $\begin{array}{c}\text { Characteristic } \\
\text { Cylinder }(\mathbf{1 5 0} \times \mathbf{3 0 0}) \\
\text { mm Compressive } \\
\text { Strength }\end{array}$ & $\begin{array}{c}\text { Equivalent Cube } \\
\mathbf{( 1 5 0 \times 1 5 0 \times 1 5 0 )} \\
\text { mm Compressive } \\
\text { Strength }\end{array}$ & $\begin{array}{c}(\mathbf{1 5 0} \times \mathbf{3 0 0 )} \mathbf{m m} \\
\text { Cylinder }\end{array}$ & $\begin{array}{c}(\mathbf{1 5 0} \times \mathbf{1 5 0} \times \mathbf{1 5 0 )} \\
\mathbf{m m} \text { Cube }\end{array}$ \\
\hline C30/37 & 30 & 37 & 36 & 43 \\
\hline
\end{tabular}

The amount of aggregate required for sieve analysis is given in Table $21[16,31]$.

Table 21. Mass of test specimens for normal aggregates.

\begin{tabular}{cc}
\hline Aggregate Grain Size (D) (up to) $\mathbf{~ m m}$ & Sample Amount Required for Experiment (minimum) $\mathbf{k g}$ \\
\hline 63 & 40 \\
32 & 10 \\
16 & 2.6 \\
8 & 0.6 \\
$<4$ & 0.2 \\
\hline
\end{tabular}

Reference concrete (RC) and optimum binder concrete (PPCC) sieve analysis were performed according to the TS EN 933-1 (2012) (EN 933-1:2012) standard [31]. As stated in TS EN 933-1 (2012) (EN 933-1:2012) for sieve analysis, $3 \mathrm{~kg}$ sample was taken considering the largest aggregate grain size in the concrete, which was $16 \mathrm{~mm}$ [31].

\section{Results and Discussion}

\subsection{Compressive Strength Test Results for Optimum Binding Ratio Determination}

Samples prepared for compressive strength tests are shown in Figure 9.

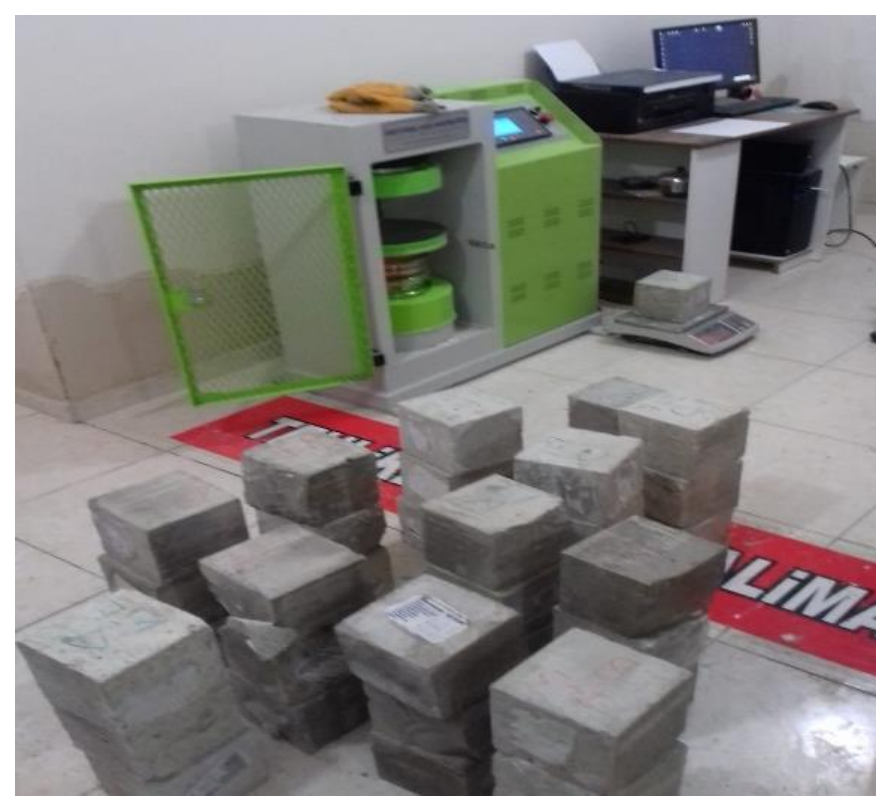

Figure 9. Samples prepared for compressive strength tests. 
The appearance of the samples in the compressive strength tester is shown in Figure 10.

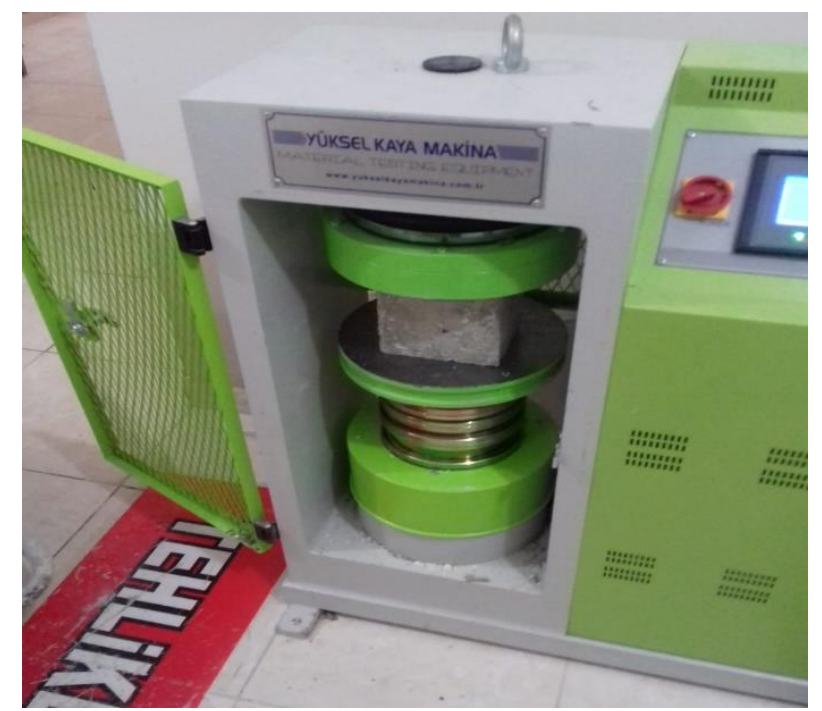

Figure 10. Appearance of samples in compressive strength tester.

The results are presented for the 7-day period Sections 3.1.1-3.1.4. Three samples for each mixture design were taken, and the average of these three values was calculated.

\subsubsection{Type-1 Compressive Strength Test Results}

Type-1 mixture quantity, unit volume weight (BHA) and compressive strength test results are shown in Table 22.

Table 22. Type-1 mixture quantity, unit volume weight and compressive strength test results.

\begin{tabular}{|c|c|c|c|c|c|c|}
\hline $\begin{array}{l}\text { Mixture } \\
\text { Type }\end{array}$ & BHA $\left(t / m^{3}\right)$ & $\begin{array}{c}\text { Cement (C) } \\
(\mathrm{kg})\end{array}$ & $\begin{array}{c}\text { Pumice } \\
\text { Powder (kg) }\end{array}$ & Lime (kg) & Water $(\mathbf{k g})$ & $\begin{array}{c}\text { Average Compressive } \\
\text { Strength (MPa) }\end{array}$ \\
\hline $1-1$ & 5.834 & 1500 & 0 & 0 & 900 & 29.7 \\
\hline $1-2$ & 5.534 & 1200 & 300 & 0 & 900 & 17.3 \\
\hline $1-3$ & 5.503 & 900 & 600 & 0 & 900 & 12.7 \\
\hline $1-4$ & 5.292 & 600 & 900 & 0 & 900 & 10.1 \\
\hline $1-5$ & 5.058 & 300 & 1200 & 0 & 900 & 7.6 \\
\hline $1-6$ & 4.850 & 0 & 1500 & 0 & 900 & 0.2 \\
\hline
\end{tabular}

Pumice powder was taken as $0 \%, 20 \%, 40 \%, 60 \%, 80 \%$ and $100 \%$ of the cement amount. The mixture 1-1 was the reference mortar of the binder paste. Only cement was used as binder in the reference mortar. According to the reference mortar, the mixture with the highest strength was the 1-2 mixture and its compressive strength was found to be 17.3 MPa.

\subsubsection{Type-2 Compressive Strength Test Results}

Type-2 mixture quantity, unit volume weight and compressive strength test results are shown in Table 23. The amounts of lime were taken as $0 \%, 20 \%, 40 \%, 60 \%, 80 \%$ and $100 \%$ of the pumice powder amount.

As can be seen in Table 23, in this section, the mixture with the highest strength was 2-3 type mixture and its compressive strength was calculated as $0.5 \mathrm{MPa}$. 
Table 23. Type-2 mixture quantity, unit volume weight and compressive strength test results.

\begin{tabular}{ccccccc}
\hline $\begin{array}{c}\text { Mixture } \\
\text { Type }\end{array}$ & BHA (t/m $\left.\mathbf{m}^{\mathbf{3}}\right)$ & $\begin{array}{c}\text { Cement }(\mathbf{C}) \\
\mathbf{( k g})\end{array}$ & $\begin{array}{c}\text { Pumice } \\
\text { Powder (kg) }\end{array}$ & Lime (kg) & Water (kg) & $\begin{array}{c}\text { Average Compressive } \\
\text { Strength (MPa) }\end{array}$ \\
\hline $2-1$ & 4.850 & 0 & 1500 & 0 & 900 & 0.2 \\
$2-2$ & 4.863 & 0 & 1200 & 300 & 900 & 0.3 \\
$2-3$ & 4.874 & 0 & 900 & 600 & 900 & 0.5 \\
$2-4$ & 4.916 & 0 & 600 & 900 & 900 & 0.4 \\
$2-5$ & 4.945 & 0 & 300 & 1200 & 900 & 0.3 \\
$2-6$ & 4.975 & 0 & 0 & 1500 & 900 & 0.2 \\
\hline
\end{tabular}

\subsubsection{Type-3 Compressive Strength Test Results}

Type-3 mixture quantity, unit volume weight and compressive strength test results are shown in Table 24 . The amounts of lime was taken as $0 \%, 20 \%, 40 \%, 60 \%, 80 \%$ and $100 \%$ of the cement amount.

Table 24. Type-3 mixture quantity, unit volume weight and compressive strength test results.

\begin{tabular}{|c|c|c|c|c|c|c|}
\hline $\begin{array}{l}\text { Mixture } \\
\text { Type }\end{array}$ & BHA $\left(t / m^{3}\right)$ & $\begin{array}{c}\text { Cement (C) } \\
(\mathrm{kg})\end{array}$ & $\begin{array}{c}\text { Pumice } \\
\text { Powder (kg) }\end{array}$ & Lime (kg) & Water (kg) & $\begin{array}{l}\text { Average Compressive } \\
\text { Strength (MPa) }\end{array}$ \\
\hline $3-1$ & 5.834 & 1500 & 0 & 0 & 900 & 29.7 \\
\hline $3-2$ & 5.806 & 1200 & 0 & 300 & 900 & 20.1 \\
\hline $3-3$ & 5.663 & 900 & 0 & 600 & 900 & 14.5 \\
\hline $3-4$ & 5.550 & 600 & 0 & 900 & 900 & 13.0 \\
\hline $3-5$ & 5.325 & 300 & 0 & 1200 & 900 & 8.1 \\
\hline $3-6$ & 4.975 & 0 & 0 & 1500 & 900 & 0.2 \\
\hline
\end{tabular}

As shown in Table 24, the 3-1 mixture was the reference mortar of the binder paste. Only cement was used as binder in the reference mortar. In this section, the mixture with the highest strength regarding reference mortar was 3-2 and its compressive strength was found to be $20.1 \mathrm{MPa}$.

\subsubsection{Type-4 Compressive Strength Test Results}

Compressive strength tests of the nine different types of mixture obtained from Type- 4 mixtures were performed and the strengths of binder pastes were calculated.

Type-1 Compressive Strength Test Results

Type-4-1 mixture quantity, weight per unit of volume and compressive strength test results are shown in Table 25. In this section, the mixing ratio with the highest compressive strength in Type-1 (Table 22) mixture was considered.

Table 25. Type-1 mixture quantity, weight per unit of volume and compression test results.

\begin{tabular}{ccccccc}
\hline $\begin{array}{c}\text { Mixture } \\
\text { Type }\end{array}$ & BHA (t/m $\left.\mathbf{m}^{\mathbf{3}}\right)$ & $\begin{array}{c}\text { Cement }(\mathbf{C}) \\
\mathbf{( k g )}\end{array}$ & $\begin{array}{c}\text { Pumice } \\
\text { Powder (kg) }\end{array}$ & Lime (kg) & Water (kg) & $\begin{array}{c}\text { Average Compressive } \\
\text { Strength (MPa) }\end{array}$ \\
\hline $4-1-1$ & 5.534 & 1200 & 300 & 0 & 900 & 17.3 \\
$4-1-2$ & 5.666 & 960 & 300 & 240 & 900 & 15.6 \\
$4-1-3$ & 5.626 & 720 & 300 & 480 & 900 & 9.6 \\
$4-1-4$ & 5.420 & 480 & 300 & 720 & 900 & 4.3 \\
$4-1-5$ & 5.198 & 240 & 300 & 960 & 900 & 1.2 \\
$4-1-6$ & 4.945 & 0 & 300 & 1200 & 900 & 1.1 \\
\hline
\end{tabular}

Accordingly, in the mixing ratio with the highest compressive strength, the amount of lime were taken as $0 \%, 20 \%, 40 \%, 60 \%, 80 \%$ and $100 \%$ of the cement amount. As shown in Table 25, the highest strength in this section was a 4-1-1 type mixture with a compressive strength of $17.3 \mathrm{MPa}$. 
Type-4-2 Compression Test Results

Type-4-2 mixture quantity, weight per unit of volume and compression test results are shown in Table 26. In this section, the mixing ratio having the highest compressive strength in the first type of mixture (Table 22) was considered.

Table 26. Type-2 mixture quantity, weight per unit of volume and compression test results.

\begin{tabular}{ccccccc}
\hline $\begin{array}{c}\text { Mixture } \\
\text { Type }\end{array}$ & BHA (t/m $\left.\mathbf{m}^{\mathbf{3}}\right)$ & $\begin{array}{c}\text { Cement }(\mathbf{C}) \\
\mathbf{( k g )}\end{array}$ & $\begin{array}{c}\text { Pumice } \\
\text { Powder (kg) }\end{array}$ & Lime (kg) & Water (kg) & $\begin{array}{c}\text { Average Compressive } \\
\text { Strength (MPa) }\end{array}$ \\
\hline $4-2-1$ & 5.534 & 1200 & 300 & 0 & 900 & 17.3 \\
$4-2-2$ & 5.559 & 1200 & 240 & 60 & 900 & 15.4 \\
$4-2-3$ & 5.624 & 1200 & 180 & 120 & 900 & 17.4 \\
$4-2-4$ & 5.717 & 1200 & 120 & 180 & 900 & 19.5 \\
$4-2-5$ & 5.780 & 1200 & 60 & 240 & 900 & 18.0 \\
$4-2-6$ & 5.806 & 1200 & 0 & 300 & 900 & $\mathbf{2 0 . 1}$ \\
\hline
\end{tabular}

In the mixing ratio, the compressive strength of which was found to be the highest, the amounts of lime were taken as $0 \%, 20 \%, 40 \%, 60 \%, 80 \%$ and $100 \%$ of the pumice powder amount. As shown in Table 26, the highest strength in this section was a 4-2-6 type mixture with a compressive strength of $20.1 \mathrm{MPa}$.

\section{Type-4-3 Compression Test Results}

Type-4-3 mixture quantity, weight per unit of volume and compression test results are shown in Table 27. In this section, the mixing ratio having the highest compressive strength in the first type of mixture (Table 22) was considered.

Table 27. Type-4-3 mixture quantity, weight per unit of volume and compression test results.

\begin{tabular}{|c|c|c|c|c|c|c|}
\hline $\begin{array}{l}\text { Mixture } \\
\text { Type }\end{array}$ & BHA $\left(t / m^{3}\right)$ & $\begin{array}{c}\text { Cement (C) } \\
(\mathrm{kg})\end{array}$ & $\begin{array}{c}\text { Pumice } \\
\text { Powder (kg) }\end{array}$ & Lime (kg) & Water (kg) & $\begin{array}{c}\text { Average Compressive } \\
\text { Strength (MPa) }\end{array}$ \\
\hline 4-3-1 & 5.534 & 1200 & 300 & 0 & 900 & 17.3 \\
\hline $4-3-2$ & 5.516 & 999 & 250.5 & 250.5 & 900 & 15.5 \\
\hline $4-3-3$ & 5.508 & 856.5 & 214.5 & 429 & 900 & 9.2 \\
\hline $4-3-4$ & 5.385 & 750 & 187.5 & 562.5 & 900 & 4.2 \\
\hline $4-3-5$ & 5.303 & 666 & 168 & 666 & 900 & 1.2 \\
\hline $4-3-6$ & 5.225 & 600 & 150 & 750 & 900 & 1.1 \\
\hline
\end{tabular}

In the mixing ratio with the highest compressive strength, the amounts of lime were taken as $0 \%$, $20 \%, 40 \%, 60 \%, 80 \%$ and $100 \%$ of the (cement + pumice powder) amount, respectively. As shown in Table 27, the highest strength in this section was a 4-3-1 type mixture with a compressive strength of 17.3 MPa.

\section{Type-4-4 Compression Test Results}

Type-4-4 mixture quantity, weight per unit of volume and compression test results are shown in Table 28. In this section, the mixing ratio having the highest compressive strength in the second type of mixture (Table 23) was considered.

In the mixing ratio, the compressive strength of which was found to be the highest, the amounts of cement were taken as $0 \%, 20 \%, 40 \%, 60 \%, 80 \%$ and $100 \%$ of the pumice powder amount. As shown in Table 28, the highest strength in this section was a 4-4-6 type mixture with a compressive strength of $20.2 \mathrm{MPa}$. 
Table 28. Type-4-4 mixture quantity, weight per unit of volume and compression test results.

\begin{tabular}{ccccccc}
\hline $\begin{array}{c}\text { Mixture } \\
\text { Type }\end{array}$ & BHA (t/m $\left.\mathbf{m}^{\mathbf{3}}\right)$ & $\begin{array}{c}\text { Cement }(\mathbf{C}) \\
\mathbf{( k g})\end{array}$ & $\begin{array}{c}\text { Pumice } \\
\text { Powder (kg) }\end{array}$ & Lime (kg) & Water (kg) & $\begin{array}{c}\text { Average Compressive } \\
\text { Strength (MPa) }\end{array}$ \\
\hline $4-4-1$ & 4.874 & 0 & 900 & 600 & 900 & 0.5 \\
$4-4-2$ & 5.152 & 150 & 750 & 600 & 900 & 1.3 \\
$4-4-3$ & 5.166 & 255 & 645 & 600 & 900 & 3.5 \\
$4-4-4$ & 5.492 & 337.5 & 562.5 & 600 & 900 & 7.0 \\
$4-4-5$ & 5.607 & 400.5 & 499.5 & 600 & 900 & 15.6 \\
$4-4-6$ & 5.710 & 450 & 450 & 600 & 900 & $\mathbf{2 0 . 2}$ \\
\hline
\end{tabular}

Type-4-5 Compression Test Results

Type-4-5 mixture quantity, weight per unit of volume and compression test results are shown in Table 29. In this section, the mixing ratio having the highest compressive strength in the second type of mixture (Table 23) was considered.

Table 29. Type-4-5 mixture quantity, weight per unit of volume and compression test results.

\begin{tabular}{|c|c|c|c|c|c|c|}
\hline $\begin{array}{l}\text { Mixture } \\
\text { Type }\end{array}$ & BHA $\left(t / \mathrm{m}^{3}\right)$ & $\begin{array}{c}\text { Cement (C) } \\
(\mathrm{kg})\end{array}$ & $\begin{array}{c}\text { Pumice } \\
\text { Powder (kg) }\end{array}$ & Lime (kg) & Water $(\mathrm{kg})$ & $\begin{array}{l}\text { Average Compressive } \\
\text { Strength (MPa) }\end{array}$ \\
\hline $4-5-1$ & 4.874 & 0 & 900 & 600 & 900 & 0.5 \\
\hline $4-5-2$ & 4.891 & 100.5 & 900 & 499.5 & 900 & 1.5 \\
\hline $4-5-3$ & 4.915 & 171 & 900 & 429 & 900 & 1.9 \\
\hline $4-5-4$ & 4.957 & 225 & 900 & 375 & 900 & 3.1 \\
\hline $4-5-5$ & 5.013 & 267 & 900 & 333 & 900 & 5.2 \\
\hline $4-5-6$ & 5.058 & 300 & 900 & 300 & 900 & 7.6 \\
\hline
\end{tabular}

In the mixing ratio, the compressive strength of which was found to be the highest, the amounts of cement were taken as $0 \%, 20 \%, 40 \%, 60 \%, 80 \%$ and $100 \%$ of the lime amount. As seen in Table 29 , the highest strength in this section was a 4-5-6 type mixture, the compressive strength of which was 7.6 MPa.

Type-4-6 Compression Test Results

Type-4-6 mixture quantity, weight per unit of volume and compression test results are shown in Table 30. In this section, the mixing ratio with the highest compressive strength in the second type of mixture (Table 23) was considered.

Table 30. Type-4-6 mixture quantity, weight per unit of volume and compression test results.

\begin{tabular}{|c|c|c|c|c|c|c|}
\hline $\begin{array}{l}\text { Mixture } \\
\text { Type }\end{array}$ & BHA $\left(t / \mathrm{m}^{3}\right)$ & $\begin{array}{l}\text { Cement (C) } \\
(\mathrm{kg})\end{array}$ & $\begin{array}{c}\text { Pumice } \\
\text { Powder (kg) }\end{array}$ & Lime (kg) & Water (kg) & $\begin{array}{l}\text { Average Compressive } \\
\text { Strength (MPa) }\end{array}$ \\
\hline $4-6-1$ & 4.874 & 0 & 900 & 600 & 900 & 0.5 \\
\hline $4-6-2$ & 4.913 & 250.5 & 750 & 499.5 & 900 & 0.9 \\
\hline $4-6-3$ & 4.951 & 429 & 642 & 429 & 900 & 4.9 \\
\hline $4-6-4$ & 4.997 & 562.5 & 562.5 & 375 & 900 & 10.2 \\
\hline $4-6-5$ & 5.015 & 666 & 501 & 333 & 900 & 15.6 \\
\hline $4-6-6$ & 5.037 & 750 & 450 & 300 & 900 & 21.9 \\
\hline
\end{tabular}

In the mixing ratio, the compressive strength of which was found to be the highest, the amounts of cement were taken as $0 \%, 20 \%, 40 \%, 60 \%, 80 \%$ and $100 \%$ of the (pumice powder + lime) amount. As seen in Table 30, the highest strength in this section was 4-6-6 type mixture, the compressive strength of which was $21.9 \mathrm{MPa}$. 
Type-4-7 Compression Test Results

Type-4-7 mixture quantity, weight per unit of volume and compression test results are shown in Table 31. In this section, the mixing ratio, having the highest compressive strength in the third type of mixture (Table 24) was considered.

Table 31. Type-4-7 mixture quantity, weight per unit of volume and compression test results.

\begin{tabular}{ccccccc}
\hline $\begin{array}{c}\text { Mixture } \\
\text { Type }\end{array}$ & BHA (t/m $\left.\mathbf{m}^{\mathbf{3}}\right)$ & $\begin{array}{c}\text { Cement }(\mathbf{C}) \\
\mathbf{( k g )}\end{array}$ & $\begin{array}{c}\text { Pumice } \\
\text { Powder (kg) }\end{array}$ & Lime (kg) & Water (kg) & $\begin{array}{c}\text { Average Compressive } \\
\text { Strength (MPa) }\end{array}$ \\
\hline $4-7-1$ & 5.806 & 1200 & 0 & 300 & 900 & $\mathbf{2 0 . 1}$ \\
$4-7-2$ & 5.607 & 960 & 240 & 300 & 900 & 15.6 \\
$4-7-3$ & 5.492 & 720 & 480 & 300 & 900 & 7.0 \\
$4-7-4$ & 5.166 & 480 & 720 & 300 & 900 & 3.5 \\
$4-7-5$ & 5.152 & 240 & 960 & 300 & 900 & 1.3 \\
$4-7-6$ & 4.863 & 0 & 1200 & 300 & 900 & 0.3 \\
\hline
\end{tabular}

In the mixing ratio, the compressive strength of which was found to be the highest, the amounts of pumice powder were taken as $0 \%, 20 \%, 40 \%, 60 \%, 80 \%$ and $100 \%$ of the cement amount. As shown in Table 31, the highest strength in this section was a 4-7-1 type mixture with a compressive strength of 20.1 MPa.

\section{Type-4-8 Compression Test Results}

Type-4-8 mixture quantity, weight per unit of volume and compression test results are shown in Table 32. In this section, the mixing ratio having the highest compressive strength in the third type mixture (Table 24) was considered.

Table 32. Type-4-8 mixture quantity, weight per unit of volume and compression test results.

\begin{tabular}{ccccccc}
\hline $\begin{array}{c}\text { Mixture } \\
\text { Type }\end{array}$ & BHA (t// $\left.\mathbf{m}^{\mathbf{3}}\right)$ & $\begin{array}{c}\text { Cement (C) } \\
\mathbf{( k g )}\end{array}$ & $\begin{array}{c}\text { Pumice } \\
\text { Powder (kg) }\end{array}$ & Lime (kg) & Water (kg) & $\begin{array}{c}\text { Average Compressive } \\
\text { Strength (MPa) }\end{array}$ \\
\hline $4-8-1$ & 5.806 & 1200 & 0 & 300 & 900 & $\mathbf{2 0 . 1}$ \\
$4-8-2$ & 5.780 & 1200 & 60 & 240 & 900 & 18.0 \\
$4-8-3$ & 5.717 & 1200 & 120 & 180 & 900 & 19.5 \\
$4-8-4$ & 5.624 & 1200 & 180 & 120 & 900 & 17.4 \\
$4-8-5$ & 5.559 & 1200 & 240 & 60 & 900 & 15.4 \\
$4-8-6$ & 5.534 & 1200 & 300 & 0 & 900 & 17.3 \\
\hline
\end{tabular}

In the mixing ratio, the compressive strength of which was found to be the highest, the amounts of pumice powder were taken as $0 \%, 20 \%, 40 \%, 60 \%, 80 \%$ and $100 \%$ of the lime amount. As shown in Table 32, the highest strength in this section was a 4-8-1 type mixture with a compressive strength of $20.1 \mathrm{MPa}$.

\section{Type-4-9 Compression Test Results}

Type-4-9 mixture quantity, weight per unit of volume and compression test results are shown in Table 33. In this section, the mixing ratio having the highest compressive strength in the third type mixture (Table 24) was considered.

In the mixing ratio, the compressive strength of which was found to be the highest, the amounts of pumice powder were taken as $0 \%, 20 \%, 40 \%, 60 \%, 80 \%$ and $100 \%$ of the (cement + lime) amount. As shown in Table 33, the highest strength in this section is a 4-9-1 type mixture with a compressive strength of $20.1 \mathrm{MPa}$. The maximum compressive strengths of each type of mixture are shown in Table 34, taking into account all mixing ratios. 
Table 33. Type-4-9 mixture quantity, weight per unit of volume and compression test results.

\begin{tabular}{ccccccc}
\hline $\begin{array}{c}\text { Mixture } \\
\text { Type }\end{array}$ & BHA (t/m $\left.\mathbf{m}^{\mathbf{3}}\right)$ & $\begin{array}{c}\text { Cement }(\mathbf{C}) \\
\mathbf{( k g})\end{array}$ & $\begin{array}{c}\text { Pumice } \\
\text { Powder (kg) }\end{array}$ & Lime (kg) & Water (kg) & $\begin{array}{c}\text { Average Compressive } \\
\text { Strength (MPa) }\end{array}$ \\
\hline $4-9-1$ & 5.806 & 1200 & 0 & 300 & 900 & $\mathbf{2 0 . 1}$ \\
$4-9-2$ & 5.516 & 999 & 250.5 & 250.5 & 900 & 15.5 \\
$4-9-3$ & 5.479 & 856.5 & 429 & 214.5 & 900 & 9.3 \\
$4-9-4$ & 5.316 & 750 & 562.5 & 187.5 & 900 & 3.9 \\
$4-9-5$ & 4.991 & 666 & 666 & 168 & 900 & 1.0 \\
$4-9-6$ & 4.976 & 600 & 750 & 150 & 900 & 0.7 \\
\hline
\end{tabular}

Table 34. Maximum compressive strength results for optimum binder fixation.

\begin{tabular}{ccccccc}
\hline $\begin{array}{c}\text { Mixture } \\
\text { Type }\end{array}$ & BHA (t/m $\left.\mathbf{m}^{\mathbf{3}}\right)$ & $\begin{array}{c}\text { Cement }(\mathbf{C}) \\
\mathbf{( k g )}\end{array}$ & $\begin{array}{c}\text { Pumice } \\
\text { Powder (kg) }\end{array}$ & Lime (kg) & Water (kg) & $\begin{array}{c}\text { Average Compressive } \\
\text { Strength (MPa) }\end{array}$ \\
\hline $1-2$ & 5.534 & 1200 & 300 & 0 & 900 & 17.3 \\
$2-3$ & 4.874 & 0 & 900 & 600 & 900 & 0.5 \\
$3-2$ & 5.806 & 1200 & 0 & 300 & 900 & 20.1 \\
$4-1-1$ & 5.534 & 1200 & 300 & 0 & 900 & 17.3 \\
$4-2-4$ & 5.717 & 1200 & 120 & 180 & 900 & 19.5 \\
$4-3-1$ & 5.534 & 1200 & 300 & 0 & 900 & 17.3 \\
$4-4-6$ & 5.710 & 450 & 450 & 600 & 900 & 7.6 \\
$4-5-6$ & 5.058 & 300 & 900 & 300 & 900 & 21.9 \\
$4-6-6$ & 5.037 & 750 & 450 & 300 & 900 & 20.1 \\
$4-7-1$ & 5.806 & 1200 & 0 & 300 & 900 & 20.1 \\
$4-8-1$ & 5.806 & 1200 & 0 & 300 & 900 & 20.1 \\
$4-9-1$ & 5.806 & 1200 & 0 & 300 & 900 & \\
\hline
\end{tabular}

As can be seen in Table 34, regarding the fixation of optimum binder ratio, the highest strength was a 4-6-6 type mixture, the compressive strength of which was $21.9 \mathrm{MPa}$.

The compressive strength test results of all mixture types are shown in Figure 11.

As shown in Figure 11, regarding the fixation of optimum binder ratio, the highest strength was a 4-6-6 type mixture, the compressive strength of which was $21.9 \mathrm{MPa}$.

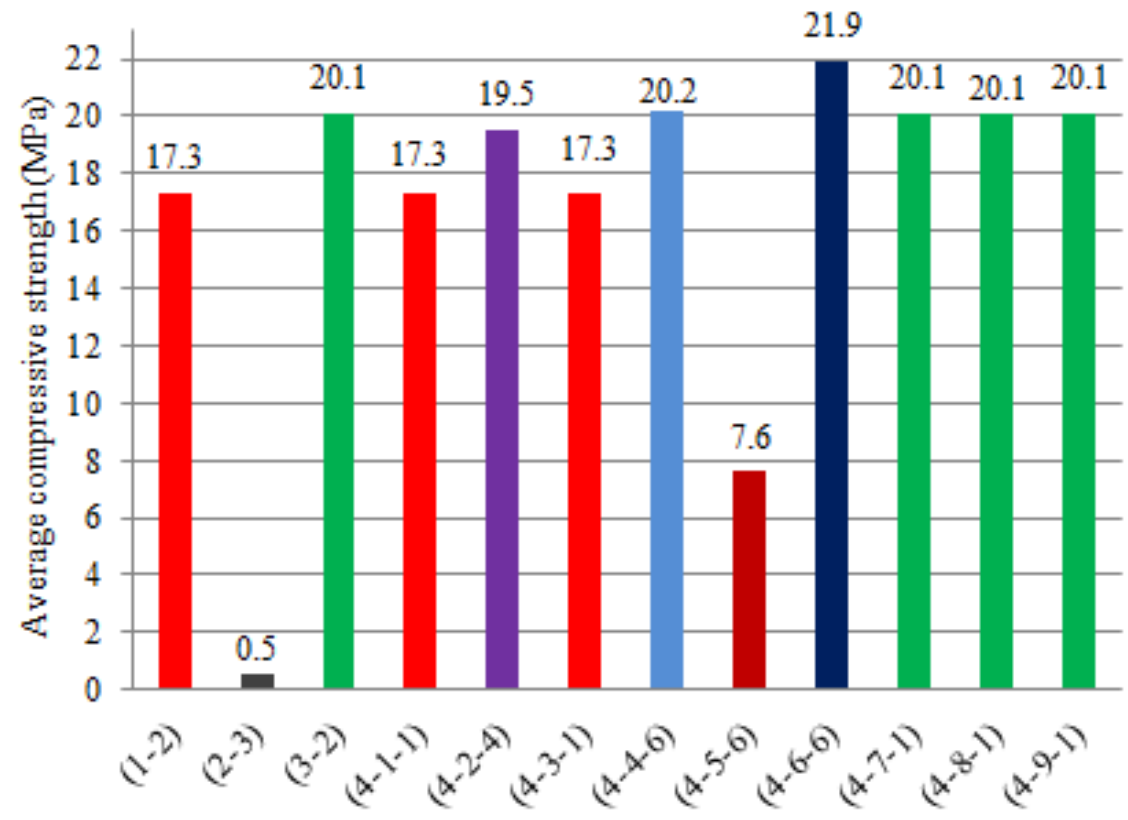

Mixture type

Figure 11. The average compressive strength test results of all mixture type. 


\subsection{Sieve Analysis Results}

Reference concrete (RC) and optimum binder concrete (PPCC) sieve analysis is shown in Table 35.

Table 35. Reference concrete (RC) and optimum binder concrete (PPCC) sieve analysis.

\begin{tabular}{ccccc}
\hline $\begin{array}{c}\text { Sieve Diameter } \\
(\mathbf{m m})\end{array}$ & $\begin{array}{c}\text { On Sieve Remaining } \\
\text { Weight (gr) }\end{array}$ & $\begin{array}{c}\text { On Sieve Total } \\
\text { Remaining Weight (gr) }\end{array}$ & $\begin{array}{c}\text { On Sieve Total } \\
\text { Remaining Weight (\%) }\end{array}$ & $\begin{array}{c}\text { Remaining Under } \\
\text { Sieve (\%) }\end{array}$ \\
\hline 16 & - & - & - & 100 \\
8 & 990 & 990 & 33 & 67 \\
4 & 660 & 1650 & 55 & 45 \\
2 & 420 & 2070 & 69 & 31 \\
1 & 300 & 2370 & 79 & 21 \\
0.5 & 270 & 2640 & 88 & 12 \\
0.25 & 210 & 2850 & 95 & 5 \\
\hline
\end{tabular}

The reference concrete (RC) and optimum binder concrete (PPCC) sieve analysis graph is shown in Figure 12.

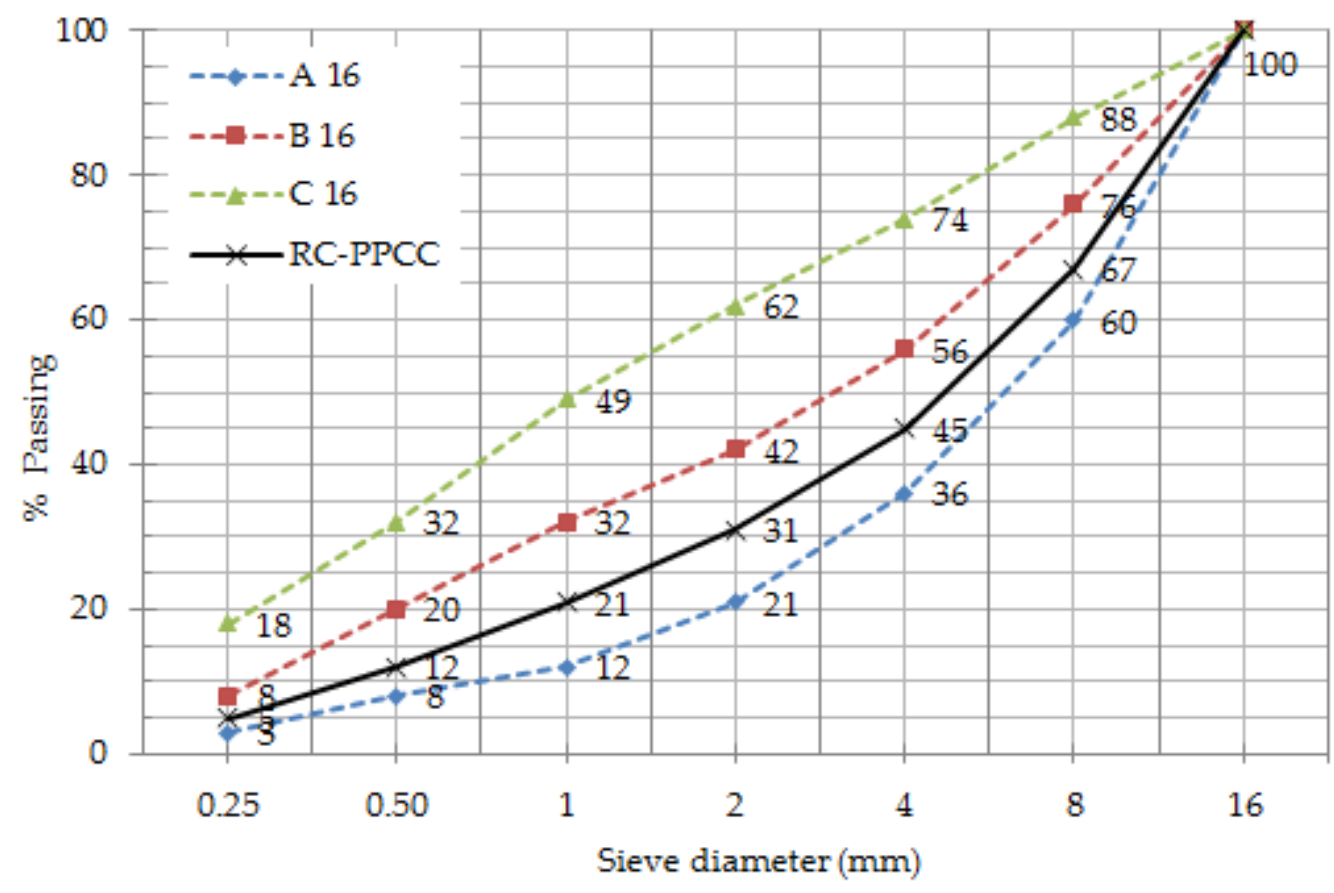

Figure 12. Reference concrete (RC) and optimum binder concrete (PPCC) sieve analysis chart.

As shown in Figure 12, aggregate granulometry of concretes conformed to TS802 (2016) standard. Standard TS 802 (2016) (ACI 211.1-91) emphasizes that the gradation curve for such aggregates must lie between lines A16 and B16 or between lines B16 and C16.

\subsection{Concrete Compressive and Bending Strength Test Results}

Table 36 shows the compressive and bending strength test results of the reference concrete (RC) and the optimum binder concrete (PPCC). The results were presented for 7-day and 28-day periods. Three samples for each mixture design under each curing condition were taken, and the average of these three values was calculated.

The average compressive strength test results of reference concrete (RC) and optimum binder concrete (PPCC) are shown in Figure 13. 
Table 36. The average compressive and bending strength test results of concrete types.

\begin{tabular}{|c|c|c|c|c|}
\hline $\begin{array}{l}\text { Concrete } \\
\text { Type }\end{array}$ & BHA $\left(t / m^{3}\right)$ & Curing Type & $\begin{array}{l}\text { Average Compressive } \\
\text { Strength (MPa) }\end{array}$ & $\begin{array}{l}\text { Average Bending } \\
\text { Strength (MPa) }\end{array}$ \\
\hline \multirow{2}{*}{$\mathrm{RC}$} & \multirow{2}{*}{2.290} & 7 days $20 \pm 2{ }^{\circ} \mathrm{C}$ water curing & 33.8 & 4.2 \\
\hline & & 28 days $20 \pm 2{ }^{\circ} \mathrm{C}$ water curing & 38.2 & 4.7 \\
\hline \multirow{2}{*}{ PPCC } & \multirow{2}{*}{2.150} & 7 days $20 \pm 2{ }^{\circ} \mathrm{C}$ water curing & 25.1 & 3.2 \\
\hline & & 28 days $20 \pm 2{ }^{\circ} \mathrm{C}$ water curing & 28.3 & 3.5 \\
\hline
\end{tabular}

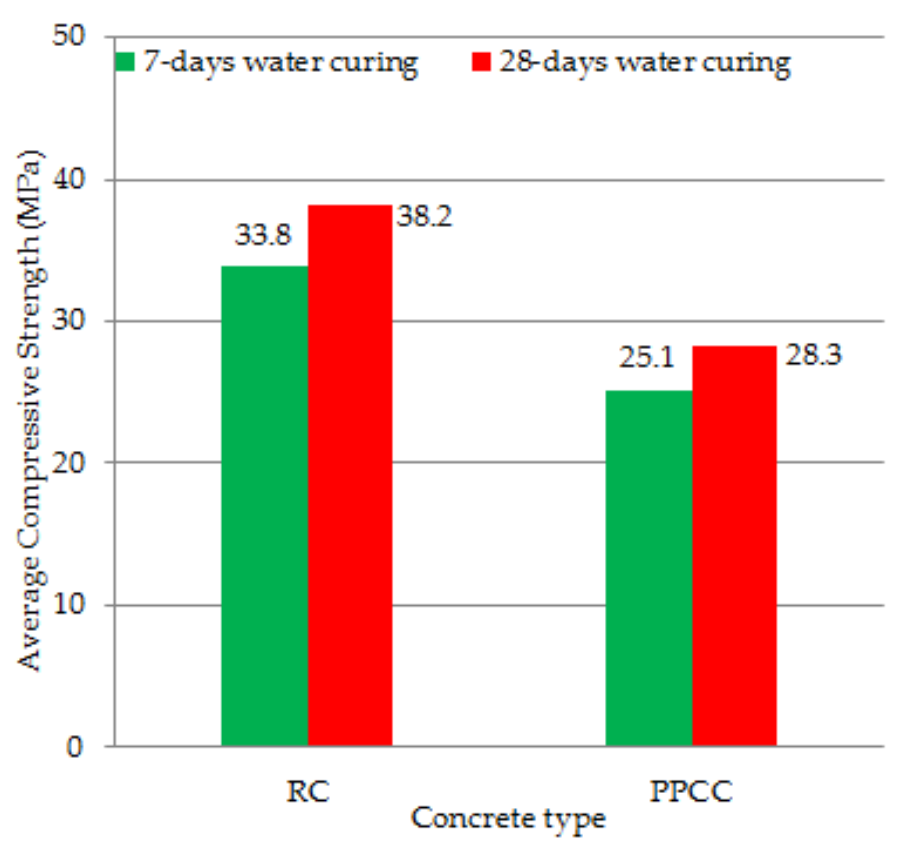

Figure 13. The average compressive strength results of RC and PPCC concrete.

The average bending strength test results of reference concrete $(\mathrm{RC})$ and optimum binder concrete (PPCC) are shown in Figure 14.

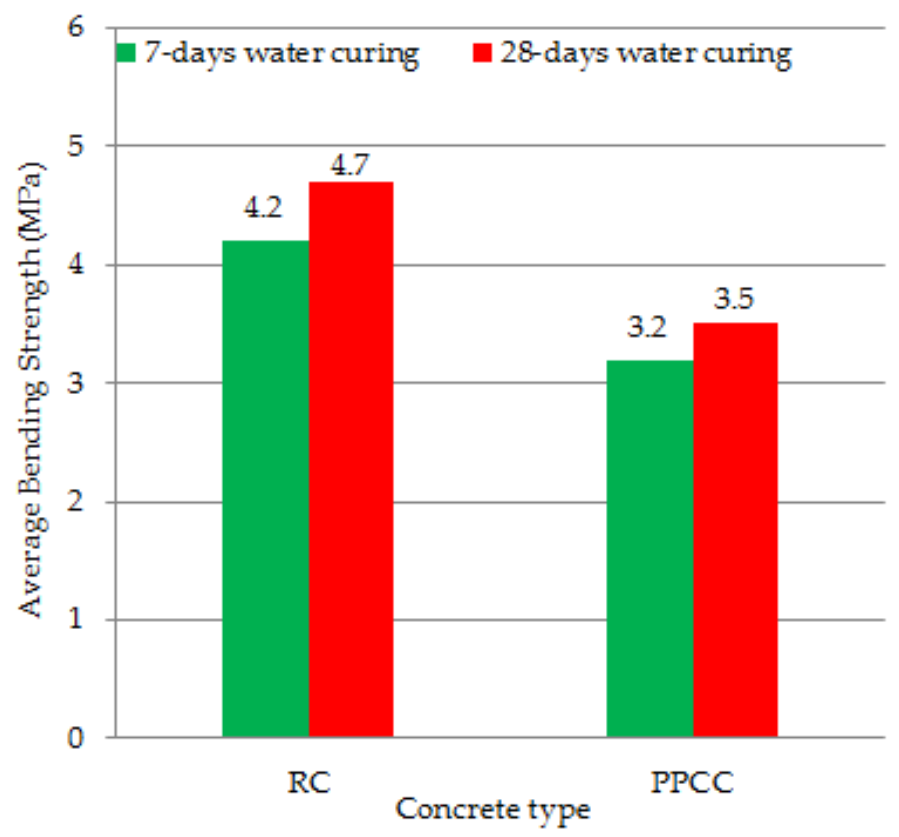

Figure 14. The average bending strength results of RC and PPCC concrete. 


\section{Conclusions}

Pumice powder is a waste material that contributes to environmental pollution and waste landfills. The presence of pores in coarse pumice gives the extremely low compressive and bending strengths, and therefore, such materials cannot be used as aggregates in concrete production. On this basis, coarse pumice has limited applicability in the construction sector. In this study, the usability of pumice powder and lime in concrete production as a binding additive for concrete road pavement was investigated. A total of 72 types of concrete samples were composed with different mixing ratios, which were formed with cement, pumice powder and lime mixtures. The most appropriate ratios of cement, pumice powder and lime as the binding additive were determined in consequence of all the experiments. Following the determination of the optimum binder ratio, these new binder ratios were used in crushed limestone concrete production. Compressive and bending strength tests of the new concrete produced were performed. The concrete thus formed was named concrete containing cement, pumice powder and lime (PPCC). The normally produced concrete, without pumice powder and lime binder was selected as reference concrete (RC). The reference concrete and PPCC concrete were cured with standard water curing of 7 and 28 days. The following results were obtained in the study:

- As a result of the study, regarding the total binder amount of the most appropriate binder ratio, $50 \%$ was found to be cement, $30 \%$ pumice powder and $20 \%$ lime;

- In consequence of the study, the $20 \pm 2{ }^{\circ} \mathrm{C}$ and 7-28 days average compressive strengths of reference concrete were found to be $33.8 \mathrm{MPa}$ and $38.2 \mathrm{MPa}$, and the average bending strengths 4.2 $\mathrm{MPa}$ and 4.7 $\mathrm{MPa}$;

- The $20 \pm 2{ }^{\circ} \mathrm{C}$ and 7-28 days daily average compressive strengths of the concrete formed by optimum binding ratio were found to be $25.1 \mathrm{MPa}$ and $28.3 \mathrm{MPa}$ and the average bending strengths 3.2 MPa and 3.5 MPa. The results of the study showed the usability of PPCC in rigid pavement;

- Subsequent studies may conduct fatigue and impact tests on the samples produced in this work.

Funding: This research has not received any specific grant from funding agencies in the public, commercial, or not-for-profit sectors.

Acknowledgments: I would like to thank Bitlis Eren University Rectorate, Dean of the Faculty of Engineering and Architecture, Hakan ÇOBAN, and Anatolia Construction Control Inc.

Conflicts of Interest: There are no conflicts of interest to declare.

\section{References}

1. Ozkan, S.G.; Tuncer, G. An Overview of Pumice Mining. In Proceedings of the 4th Industrial Raw Materials Symposium, Izmir, Turkey, 18-19 October 2001; pp. 200-207. Available online: http://www.maden.org.tr/ resimler/ekler/ecd070e606afbf0_ek.pdf (accessed on 1 January 2019).

2. Gunduz, L.; Sariisik, A.; Tozacan, B.; Davraz, M.; Ugur, I.; Cankıran, O. Pumice Technology, 1st ed.; Isbas A.S. and SDU College of Engineering: Isparta, Turkey, 1998; pp. 100-285.

3. Anon. Industrial Raw Materials Sub-Commission Building Materials, 3rd ed.; DPT: Ankara, Turkey, 2001; pp. 3-23.

4. Akin, G.; Akin, M. Properties of Pumice, Uses and Problems in Production. In Proceedings of the 2nd International Ahlat-Eurasia Symposium on Science, Culture and Art, Bitlis, Turkey, 25-27 September 2013; p. 688.

5. Dincer, I.; Orhan, A.; Coban, S. Feasibility Report of Pumice Research and Application Center; Nevsehir Haci Bektas Veli University, Department of Geological Engineering: Nevsehir, Turkey, 2015; pp. 18-23.

6. General Directorate of Mineral Research and Explorations. Available online: http://www.mta.gov.tr (accessed on 1 January 2019).

7. Varol, O.O. A general overview of pumice mining in van and Bitlis provinces. Sci. Min. J. 2016, 55, 27-34. Available online: https://dergipark.org.tr/madencilik/issue/32397/360346 (accessed on 1 January 2019).

8. Karaman, E.M.; Kibici, Y. Basic Principles of Geology, 2nd ed.; Belen Publishing and Printing: Ankara, Turkey, 2008; pp. 103-121. 
9. Unsal, N. Geology for Civil Engineers; Alp Publishing House: Ankara, Turkey, 2006; pp. 143-147.

10. Onem, Y. Industrial Mines; Kozan Offset Printing Press: Ankara, Turkey, 2000; pp. 223-230.

11. Turkel, S.; Kadiroglu, B.; Investigation on mechanical properties of structural lightweight concrete made with pumice aggregate. Pamukkale Univ. J. Eng. Sci. 2007, 13, 353-359. Available online: http://pajes.pau.edu. tr/jvi.asp?pdir=pajes\&plng=tur\&un=PAJES-92332 (accessed on 1 January 2019).

12. Oguz, C.; Turker, F. Relations between Physical and Mechanical Properties in Pumice Concrete. In Proceedings of the 1st Isparta Pumice Symposium, Isparta, Turkey, 26-28 June 1997; pp. 81-87.

13. Bakis, A. Investigation on the Usability of Reactive Powder Concrete (RPC) in Rigid Road Superstructure Construction. Ph.D. Thesis, Ataturk University, Erzurum, Turkey, 2015.

14. Tunc, A. Road Materials and Applications, 2nd ed.; Nobel Publication Distribution: Ankara, Turkey, 2007; pp. 123-131.

15. Bedirhanoğlu, İdris. Building Material and Concrete Design; Dicle University: Diyarbakir, Turkey, 2011; pp. 13-26.

16. Dal, M.; Kilinc, C.; Eren, E.; Isik, A. Concrete Technology and Concrete Technology Laboratory; Economic Foundation of Architecture: Istanbul, Turkey, 2013; pp. 143-157.

17. Baradan, B.; Yazıcı, H.; Aydın, S. Concrete; Dokuz Eylul University, Faculty of Engineering Publications: Izmir, Turkey, 2012; pp. 8-12.

18. Hattatoglu, F.; Bakis, A. Usability of ignimbrite powder in reactive powder concrete road pavement. RMPD 2017, 18, 1448-1459. [CrossRef]

19. TS EN 197-1 (EN 197-1:2011). Cement-Part. 1: Composition, Specifications and Conformity Criteria for Common Cements; TSE: Ankara, Turkey, 2012; pp. 3-9.

20. Cimsa Cement Industry and Trade Inc. Available online: https://www.cimsa.com.tr (accessed on 1 January 2019).

21. Miner Mining Transportation Trade Limited Company. Available online: http://www.miner.com.tr (accessed on 1 January 2019).

22. TS EN 459-1 (EN 459-1:2015). Building Lime-Part 1: Definitions, Specifications and Conformity Criteria; TSE: Ankara, Turkey, 2017; pp. 4-12.

23. Efe, T. Investigation of Applicability of Edremit Travertine and Pumices Outcropping North of Van Lake in Cement Sector. Master's Thesis, Yuzuncu Yil University, Van, Turkey, 2011.

24. Nuh Construction Products Inc. Available online: https://www.nuhyapi.com.tr (accessed on 1 January 2019).

25. TS 25 (TS 25/T1). Natural Pozzolan (Trass) for Use in Cement and Concrete-Definitions, Requirements and Conformity Criteria; TSE: Ankara, Turkey, 2008; pp. 7-10.

26. Aslan, M. Perlite, Ahlat Stone and Pumice Aggregates for Use in Stone Mastic Asphalt Pavement. Master's Thesis, Bitlis Eren University, Bitlis, Turkey, 2018.

27. Limak Cement Industry and Trade Inc. Available online: http://www.limakcement.com (accessed on 1 January 2019).

28. TS EN 12390-3 (EN 12390-3/2001). Testing Hardened Concrete-Part 3: Compressive Strength of Test Specimens; TSE: Ankara, Turkey, 2010; pp. 7-9.

29. TS EN 12390-5 (EN 12390-5:2000). Testing hardened concrete-Part 5: Flexural strength of test specimens; TSE: Ankara, Turkey, 2010; pp. 12-17.

30. TS 802 (ACI 211.1-91). Design of Concrete Mixes; TSE: Ankara, Turkey, 2016; pp. 5-9.

31. TS EN 933-1 (EN 933-1:2012). Tests for Geometrical Properties of Aggregates-Part. 1: Determination of Particle Size Distribution-Sieving Method; TSE: Ankara, Turkey, 2012; pp. 1-10.

(C) 2019 by the author. Licensee MDPI, Basel, Switzerland. This article is an open access article distributed under the terms and conditions of the Creative Commons Attribution (CC BY) license (http://creativecommons.org/licenses/by/4.0/). 